\title{
2-Stage Europeanisation and Constitutional Courts in Germany, Austria and Italy
}

\author{
Nicola Ch. Corkin ${ }^{1}$ \\ ${ }^{1}$ University of Exeter, UK \\ Correspondence: Nicola Ch. Corkin, 6/5 Christchurch New Buildings, Woodbine Place, Oxford, OX1 1LB, UK. \\ E-mail: nicola.corkin@sthughs-oxford.com
}

Received: June 3, 2013 Accepted: June 17, 2013 Online Published: November 29, 2013

doi:10.5539/jpl.v6n4p46 URL: http://dx.doi.org/10.5539/jpl.v6n4p46

\begin{abstract}
This paper argues that a 2-Stage Process of Europeanisation can be found in Germany's, Austria's, and Italy's constitutional courts. The first stage can be analysed with conventional rational choice based Europeanisation theories but these theories fall short in providing insight into the second stage. In this stage courts change their self-perception and role-perception leading to a change in their logic of appropriateness in their decision-making. Therefore, an approach synthesising aspects of sociological institutional, organisational theory and learning theories are best suited to account for this second stage. Data, both statistical and content analysis, taken from the constitutional court jurisdictions in Germany, Austria and Italy between 1980-2012 are then tested against this 2-stage approach.
\end{abstract}

Keywords: abstract judicial review, constitutional courts, Europeanisation, learning, sociological institutionalism and organisation theory

\section{Introduction}

A 2-Stage Europeanisation process, one stage vertical and one horizontal, has occurred in abstract judicial review leading to a convergence in the conceptualisation of social norms. Common rational choice based Europeanisation theories capture the first stage, but the second stage demands a wider approach to the theory of Europeanisation. Consequently, the paper will summarise the different strands of Europeanisation theory initially before concentrating on their application to courts and national jurisdictions. The theories overarching weakness is found to lie in their inability to allow for normative changes and developments outside the formal opportunity pathways established in political and institutional intercourse. This inability is based on the methodological difficulty to empirically capture informal influences, such as changes in social norms. The second part of the paper outlines the empirical need of a wider theoretical framework as evidenced through the changing patterns in court decisions. Finally, theories borrowed from social psychology and sociology regarding social norms and their influence on individual, as well as group, behaviour, are used for a broader definition of the process of Europeanisation as it applies to courts. Data from the jurisdictions of the German, Austrian and Italian constitutional courts is tested against the broader theory and illustrates this 2-stage development and the influence of non-formal aspects of Europeanisation on concrete decision-making. In conclusion, alternative theories are considered but are found to be unable to account sufficiently for the increased "European influence" in the national jurisdictions.

\section{Europeanisation - a Definition and Its Problems}

In this first section, the paper provides an overview of existing Europeanisation theory, especially in conjunction to courts, and the methodological difficulties presented by their study. Europeanisation is not comprehensively defined as a unitary concept, therefore, in order to allow for an application to European courts, it is necessary to first consider the most prevalent nominal and operational definitions: Europeanisation as a) a situation and as b) a process (Ladrech, 2010). Europeanisation as a situation is defined as "distinct modes of European governance have transformed aspects of domestic politics" (Buller \& Gamble, 2002: 26). In the situational definition, it forms the dependent variable, conceptualising the outcome of change at the domestic level (Hix, 2000). As a process its understanding rests on its position as an independent variable within the research framework. The concept is defined as a "process of construction, diffusion, and institutionalisation of formal and informal rules, procedures, policy paradigms, styles, "ways of doing things" and shared beliefs and norms which are first defined and consolidated in the making of EU decisions and then incorporated into the logic of domestic discourse" (Radaelli, 
2003: 30). A possible explanation for the lack of a single fixed definition of the term Europeanisation can be the desire to allow for informal, as well as formal, aspects of Europeanisation in research (Radaelli, 2000: 4). There have been attempts to narrow down the concept of Europeanisation they are hampered by their specification to single areas of studies rather than providing a subject(s) overarching understanding of the term (Olson, 2002).

Both definitions of Europeanisation, as a process and as a situation, are nominal in nature and need expansion to serve as a guideline of how to measure the extent or occurrence of Europeanisation. There is therefore need for an operational definition in conjunction with the nominal ones above. In its nature the process definition lends itself best to provide a clear operational definition. Drawing on aspects of new institutionalism, scholars have given a more detailed description of Europeanisation as a process (Boerzel \& Risse, 2000; Risse, Cowles et al., 2001; Ladrech, 2010): If there is a discrepancy between domestic policy structures and EU policy structures then pressures to adapt to the EU policy structures are formed at the domestic level. They argue that the extent to which domestic politics is changed through these adaptational pressures is based on the level of domestic power dispersion, public access to opportunity structures, political culture and norm development. (Risse, Cowles et al., 2001; Boerzel \& Cichowski, 2003; Ladrech, 2010: 34). The resulting domestic change can be widely differing and even continually changing as a result to these intervening variables. Domestic reactions may range from inertia to full transformation, moving through "resistance to changes" over "low degrees of change" and "adaptation without changing the core features of a policy environment" (Boerzel, 2005; Boerzel \& Risse, 2007; Ladrech, 2010: 35). The problem with this definition is the lack of demarcation. When does the process of Europeanisation begin? When does it stop? How does it differ from European integration?

Europeanisation as a situation faces similar problems of demarcation in its operational definition. A Europeanised situation has to have a distinct "before", a non-Europeanised situation - and a method of measuring the two states. It also needs to be clearly demarcated from European Integration, if it is not to become a "rose by any other name". Therefore, Europeanisation as dependent variable, as a situation, faces the problem that, as nominal definition, it lacks empirical practicability whilst Europeanisation as a process, as independent variable, is unable to account for the goal of the process. Both definitions contain problematic aspects regarding alignment of conceptual and empirical observations: concept stretching (lack of demarcation), concept atrophy (too narrow to be externally valid), or even internal validity (Radaelli, 2000; Buller \& Gamble, 2002; Howell, 2004).

The empirical indicators should capture and express the aspects of the theoretical concept they stand for to ensure validity, internally and externally, of a concept. Internally, there should be indication that the concept under research, in this instance Europeanisation, rather than any other concept is the route source of the change (King, Keohane et al., 1994; Haverland, 2003). For both, Europeanisation as a process and Europeanisation as a situation, validity is difficult to ascertain as "everything is touched by Europe" (Radaelli, 2000). It is therefore often difficult to ascertain that a change has occurred due to European influence. The process definition also falls short in giving clear indications as to what are the concrete, observable end-products of Europeanisation. The situational definition might be able to resolve this but there needs to be a clearer conceptual attempt to match external validity in terms of empirical research. Europeanisation as a situation needs to allow for a clear and demarcated pathway between the non-Europeanised and Europeanised situation which is not accounted for by European integration and gives insight into a general phenomena.

The problem with concept stretching and concept atrophy is expressed through the "top-down" approach of both definitions (the clear necessitation of linking supranational instances with national ones), which leaves little room for explanations of horizontal influences; although it is not able to exclude them (Howell, 2004). Horizontal Europeanisation, as a process, identifies "policy misfit" between already Europeanised and not yet Europeanised policy areas, which created pressures to adapt the not yet Europeanised policy areas to the opportunity structures in the Europeanised policy areas. The result is a further spread in Europeanisation. However, this is dangerously close to the definition of "spill-over" in European Integration theory. It might be argued that the concept is stretched beyond use here. Radaelli (Radaelli, 2000; Radaelli, 2004) argues that the difference lies in the stage or level of research. European integration theory is an ontological theory answering the question why states chose to engage in supranational forms of governance. Europeanisation, on the other hand, looks at the process of how policy areas adapt after the states have decided to integrate. This is a useful demarcation but still needs to find its expression in actual nominal or operational definitional formulations of the concept.

A useful definition therefore needs to give some clear expression of what is "European influence", what is "Europeanised", how this "European influence" links the national and supranational level and where this influence stops, addressing problems of demarcation and conceptual validity. With other words, Europeanisation definitions need to allow for vertical as well as horizontal forms of Europeanisation without losing internal validity and giving clear expressions to empirically measurable aspects of the theoretical concept. There is also a question in how far 
this differs, or complements, the theories of judicial comity and epistemic communities. Furthermore, there have been recent claims of backlashes against European integration in the form of the counter-limits and the ultra vires doctrines and it needs to be explained if the theory of Europeanisation can account for these instances of retrenching or reversal.

\subsection{Europeanisation and Courts}

Europeanisation studies of the courts have tried to answer this challenge but have fallen into the pitfall of concept atrophy. The study of courts allows for clear pathways of research through the strict procedural rules and hierarchy within the field of European law. If the hierarchy is invoked, clear lines of responsibility lead from the lowest national courts up to the European Court of Justice (ECJ) and these can be followed empirically by taking account of Article 267 references and preliminary ruling procedures (Conant, 2001; Conant, 2002). With other words, the level of Europeanisation is measured on the number of references to the European Court of Justice or on the relative annual increase of these references to the European Court of Justice. This seemingly addresses the difficulty of a) what is "European influence", namely an Article 267 reference; b) how the national and supranational levels are linked, namely through the relation between national courts and the European Court of Justice (ECJ) and c) how and where this influence stops. But it has serious shortcomings in the restrictive nature of the definition as well as limiting Europeanisation to a situational occurrence within courts rather than a developmental process.

The first question is therefore what is the "Europeanisation" - what is the "European influence" - being exerted? In regards to courts, Article 267 references have a long pedigree in research as conceptual indicators for a legal functional logic (Mancini, 1991; Wincott, 2000; de Burca \& Weiler, 2001), the accommodation of national interest (Garrett, Kelemen et al., 1998), the self-interest of actors (Slaughter, Stone Sweet et al., 1998), inter-court competition and pressure group acceptance of the European level (Alter, 2001). The argument in all these studies is that the use of preliminary references are evidence for the formulaic incorporation of the supranational level into the national legal understanding, and this is evidence of Europeanisation as a situation. As a process, the argument is linked more to the rational choice understanding of the institutionalist school of thought and can be summarised as follows: The opportunity structure has changed through EU membership, leading to a policy misfit and adaptational pressures to make use of these altered opportunity structures (Peters, 2005). Policy and judicial review competencies are transferred from the national to the supranational, the EU level in the form of the EU institutions, including the European Court of Justice (Howell, 2004). This shifts the power balance from a national to a supranational level and creates a new opportunity structure. As a result, a misfit between national and supranational levels policy levels occurs (Boerzel \& Risse, 2000). A new opportunity structure supplants the old purely domestic one and allows domestic and supranational agents to make use and develop new influence pathways. Local agents in one policy area use the pathway to the European Court of Justice to pressure for domestic change. Therefore, adaptational pressures from the supranational level to the domestic level lead to an incentive to domestic change. Moreover, domestic change in one policy area creates an incentive to change in other areas, leading to further Europeanisation.

The extent to which domestic change in the form of Europeanisation occurs is an aggregate of the number of veto players and institutional fit (Ladrech, 2010: 43). In respect to courts and the clear hierarchical structure in which courts act, it is comparatively transparent to define both the possible veto points and the institutional fit between the national and supranational level. The institutional fit between the member states and the supranational level differs widely. The European Court of Justice (ECJ) is modelled on the courts of the original members - civil law countries with courts that allow for judicial review of administrative acts. The ECJ originally was not designed with the power of judicial review of domestic national acts for their constitutionality in accordance with European Union legislation. This is a power that developed over time, many have argued as a result of judicial activism by the court, or European courts in general (Wincott, 2000; Alter, 2001; Craig \& Burca, 2003). Others see it as a result of internal role perceptions: judicial review was perceived as a natural power of a court, therefore leading to a closer fit between the domestic structures of the original member states and the newly founded EU level institutions (Mancini, 1991; Mattli \& Slaughter, 1998). The result is that countries such as Germany, Italy, France, Luxembourg and Belgium (though not the Netherlands) have a very similar court system to that of the European Court of Justice.

To understand the problem of concept atrophy in regards to Europeanisation attention needs to be payed to the internal workings of court systems. The development of the Europeanisation definition in relation to courts allows for external validity to most courts in Europe, due to their institutional fit - but this depends strongly on the format of judicial review studied. Court systems across Europe are largely comparative due to historical and theoretical congruence and, over the last three decades, active design but they are not unitary within; rather they are a 
conglomeration of many different forms of judicial review: review of a concrete case, review of a general law, conflicts between organs of state and so on. Article 267 only applies to a very small amount of these - direct review of concrete cases.

Historically, most European courts have been designed following a period of authoritarian rule and their design reflects this historical trend (Harding \& Leyland, 2009: 4). Traditionally, three distinct court models have been identified within Europe: a common law model and two separate civil law systems: an Austro-German model and a Francophone model. The main difference between the models lies in the form and extent of the ability of high courts to engage in judicial review of legislation (Rogowski \& Gawron, 2002; Comella, 2009: 5). In the UK, the only true common law system in Europe, judicial review of primary legislation is limited by the concept of parliamentary supremacy (Barnett, 2004). The francophone system, found in France and Romania, is demarcated through its limitation of the constitutional courts to abstract review prior to promulgation. Primary legislation is reviewed, not in application to a specific case but in its theoretical entity as words on the page. After promulgation, when the law is being applied within the national jurisdiction, the constitutional court is unable to judge the constitutionality of primary legislation (Note 1). In the Austro-German system, on which most constitutional courts in Europe are modelled, the constitutional review of legislation, in abstract as well as in direct application to a case, was always and only possible by the constitutional court (Jackson and Tate, 1992: 5). This has changed significantly since the inception of the European Court of Justice and the preliminary ruling procedure (Article 267 Treaty on the Functioning of the European Union) regarding the application of a law to a direct case but not regarding the abstract review of a case (de Burca \& Weiler, 2001; Craig \& Burca, 2003). National courts can directly apply to the ECJ, not the constitutional court, if a question on the adherence to EU law or national law arises. A pathway has been created between the national and supranational level through this for of judicial review.

This clear systemic link between national jurisdictions and the European Court of Justice allows researchers to concentrate on measuring levels of preliminary references as indication of Europeanisation (Slaughter, Stone Sweet et al., 1998). In the top-down definition of Europeanisation this is not problematic, it is even supremely suited to such an analysis. The ECJ and preliminary rulings created a new opportunity structure on the EU level leading to a policy optimisation misfit on the national levels. As a result the national courts adapted using the supranational opportunity structures therefore leading to Europeanisation on the national level. However, as such it is also prone to the criticisms of concept atrophy - possibly more so than other areas of policy-making. For one, Article 267 references, preliminary ruling requests, can only be in relation to direct review by lower courts. However, constitutional courts engage in a wide range of powers aside from direct judicial review and Article 267 references. A strict "top-down" approach to Europeanisation would assume that there is no empirically observable European influence on non-Article 267 jurisdiction. A second criticism argues that (for concept validity to hold) there needs to be a clear empirical link between the EU level specific policies and the national level specific cases, which excludes any analysis outside of Article 267 and direct review emphasising concept atrophy. However, it remains to be seen if an analysis outside of Article 267 is even empirically possible.

\subsection{Methodological Difficulties and Case Selection}

The difficulties with the conceptual components are highlighted through a consideration of the characteristics of court systems and their influence on case selection. Research concentrated on preliminary rulings can only touch a very small part of the jurisdictions of court systems - and arguably the least controversial. A definition outside of preliminary rulings, on the other hand, faces questions of the measurability of "European influence" taken in an informal context.

\subsubsection{Case Selection and Why a Concentration on Abstract Judicial Review in Europe}

As noted above three common court models can be identified in Europe with the Austrian-German model being the most prevalent. So, to preserve comparability and ensure validity, empirical analysis will be limited to the Austro-German model of constitutional courts. Court behaviour and position in the political hierarchy is influenced by its age and perception of legitimacy (Epstein, Knight et al., 2001; Kramer, 2007). A choice of political systems with constitutional courts not only from comparable systems but also of comparable age seems advisable. The German, Austrian and Italian Constitutional Courts are obvious choices for an analysis as they all were founded after World War II in response to authoritarian rule. Regarding an analysis of Europeanisation this choice of constitutional courts has the additional advantage of adding the dimension of differing EU membership spans. Italy and Germany both are among the original members of the EU whilst Austria only joined in 1995. Europeanisation theory therefore would assume in s strict "top-down" approach that there is 
1. Europeanisation in direct review, as has been shown in previous studies, but not in abstract review including Organstreit (competence conflict between two political institutions) in Germany, Austria and Italy (Alter, 2001; Conant, 2001; Stone Sweet \& Sandholtz, 2001)

2. Europeanisation occurs in Austria only after EU membership or at least after application in 1990.

3. European influence is limited to Article 267 references or at least can be directly linked to specific European policies.

Moreover, concentration on abstract judicial review, where there is no formal link between the national and supranational level, will allow for an analysis of European influence outside of Article 267 references. The disadvantage of concentrating on abstract judicial review lies in the comparable scarcity of cases. Whist direct review produces between 3000 and 5000 cases a year in Germany, in Austria and in Italy abstract judicial review only produces between 3 and 40 cases. The relative scarcity of cases is however outweighed by the importance of abstract judicial review. Abstract judicial review is invoked exclusively by a public power such as a political institution, the head of state, a regional unit or, exceptionally, by groups of parliamentarians. Most importantly, the cases are of political importance as the decision is not on the application of a norm to a particular case but rather on the law in all its applications and permutations. Moreover, the relatively small number of cases allows for a longterm analysis of the entirety of the caseload rather than presenting the researcher with the necessity of drawing a sample.

\subsubsection{Is There Methodological Space for an Analysis outside Article 267 - Theoretical Considerations}

A study outside the parameters of Article 267 must attempt to measure "European influence" independent of Article 267 references. What is influence? What is it that does the influencing? Influence, as social influence, relates to non-physical interactions between humans or institutions, rather than physical influence such as gravity (Aronson, 2004). Research in social influence is closely linked with social norms and their standing in society. A social norm is behaviour or opinions shared by a defined group which describe acceptable behaviour patterns within this group. Jon Elster describes them as non-outcome orientated and as sustained through anxiety, embarrassment or social stricture (Elster, 1998: 100). Social norms can be separated into descriptive and injunctive norms. Descriptive norms describe pattern of common behaviour and strategies of action, which we have accepted as normal - non regarding their ethical or legal implications. A good example is sharing music, the copying of a cd or mp3 files for a friend. It has become accepted behaviour in society merely through the volume of people undertaking it but it is illegal and theft. The rightness or wrongness of the action is, more often or not, not even in debate. Injunctive norms, on the other hand, specify what people consider and approve of as "good" and "acceptable" actions and motivations. Injunctive norms generally garner social sanctions, even if these sanctions may be merely social discomfort. Injunctive norms have been shown to be more resilient and effective than descriptive norms (Reno, Cialdini et al., 1993: 104). This creates a quiet system of acceptable behaviour and motivations, of normative and counter-normative actions and motivations, within a group and the wider society (Sunstein, 1996; Kahan, 1997). Influence therefore is the alteration of behaviour, consciously or unconsciously, based on accepted norms and behaviours.

For a long time, the study of courts especially, refused to engage in the consideration of social norms as significant in research. This led to an overestimation of the influence of legal factors over, in many cases to the exclusion to, other social factors (Sunstein, 1996). Recent years have, however, shown a rising awareness of social factors in respect to criminal courts and, later supreme and constitutional courts (Kahan, 1997). The reason why social norms have remained relatively minor in research is the relative difficulty in measuring them with any level of confidence (Labovitz \& Hagedorn, 1973; Camerer \& Fehr, 2002). They are by definition something vague and often only subconsciously realised. How do you measure something so intangible? Attempts have been made in sociology and criminal law to answer this question (Lessig, 1996; Sunstein, 1996; Schultz, Nolan et al., 2007). These studies do not doubt the existence of social norms, but rather ask in how far these norms influence human behaviour and what form they take (Lessig, 1996; Camerer \& Fehr, 2002). This paper assumes that there are social norms relevant in decision-making. It posits that there has been a change in what is considered acceptable behaviour, a social norm, in the decision-making of courts by the introduction of a "European norm". This is an injunctive norm, altering the framework of what is acceptable in behaviour and therefore influencing decision-making.

The question still remains how to measure these "European norms". Classical Europeanisation theory posits that Europeanisation is a reaction to a change in the opportunity structures surrounding institutions (Boerzel, 2005). The number of Article 267 references are used as empirical evidence for this adaptation to an altered opportunity structure (Conant, 2001). Sociological institutionalists have argued that this change in the opportunity structures can be normative, a change in acceptable social norms motivating and influencing groups or institutions (Peters, 
2005: 128). Norms are what is acceptable or perceived as legitimate within a given group. For instance, basing a decision by the US Supreme Court on a racist argument today would be perceived within the Court itself as illegitimate - the same is not the case in a militia group with a racist agenda (Note 2). They therefore find their expression also in the text of decisions and can be measured there

To study the change of norms it therefore should be possible to engage in content analysis of the texts of decisions to determine which arguments, aside from legal references, have been seen as acceptable, as legitimate, over time. For this purpose, all the abstract norm decisions in Germany, Austria, and Italy for the period 1980 to 2010 have been collated and analysed. Counting based on individual plaintiffs leads to 1529 cases across the three decades with the majority of cases based in Italy (1064). The cases in Germany and Austria are easily identifiable through their legal reference (BvF (Germany), G (Austria)) within the caseload of the courts and all are accessible online or via documentation published by the courts. Whilst the cases are also accessible online in Italy they lack a clear identification within the caseload and there was the necessity to identify cases manually. Germany has the lowest number of abstract judicial review cases, 163 whereas in Austria the number is 300. These highly disparate numbers are a product of different political cultures. In deference to these differences the analysis necessitated percentile display of the data. The content analysis then concentrated on informal norm constructions containing the words European, International or community. Excluded from this analysis are all formal references to laws, regulations or guidelines, European or International, as well as the jurisdiction of the European Court of Justice, such as Article 267. Therefore it is possible to consider court developments based on normative arguments and developments - even in respect to Europeanisation. This analysis then allows for a consideration if there is any potential Europeanisation outside of Article 267.

\section{Is There Empirical Space and Need for an Analysis outside Article 267?}

In this second part of the argument I will present an argument on why there is an empirical and theoretical need to examine Europeanisation outside of Article 267 references. The number and development of Article 267 references have been well documented over time (Slaughter, Stone Sweet et al., 1998; Alter, 2001; Conant, 2001; de Burca \& Weiler, 2001). Other forms of "European influence" are beginning to be noticed as well; courts refer to EU law in judicial review within the EU and outside (Slepcevic, 2009; Slaughter, 2012: 5). This is a natural development of the increase in EU law in general (Note 3). In Germany, the constitutional court rarely referred to EC law prior to 1989, today more than half contain references to EU law in the legal argument (similar to Austria and Italy). Increased permeation of national law by references to EU legislations, regulations and directives are expected and logical following increased integration. They are a direct result of the link between the ECJ and national courts as well as provide a clear link between Europeanisation on the national level and EU regulations and directives. Classical Europeanisation theory, or even European integration theory, can easily account and accept these formal links between the European and the national political spheres (Ladrech, 2010).

More interesting, for Europeanisation and beyond, is the development of informal references to the "European" the recurring mention of "European values" and "European obligations", independent of particular regulations or directives. In Germany and Italy, of the cases containing a reference to extra national concepts over $60 \%$ now utilise "European values and norms", "community obligations" and "European legal unity" and other forms of informal references such as (e.g. (103/2008), (134/2006), (206/2001), (356/1998), (94/1995)):

" ... in relation to the period of completion of the process of liberalisation and European integration ..." $(1 / 2008)$

"In a globalised and integrated economy .... rises the need for higher indirect, but social in their usage, purpose independent taxation" $1 \mathrm{BvF} 1 / 05$

“...(in this he) simply fulfilled the obligations existent in a framework of a European economic community ..."2BvF3/03

In Austria, a similar development can be observed even before EU Membership.

"These arguments as a whole become overwhelmingly convincing in connection with the treaty negotiations with the European Communities" (G245/89).

In other instances, the plaintiffs have begun to argue that a decision is "an euro-political necessity" (388/1996) and in "accordance with the intentions of the European Institutions" (189/1990). 


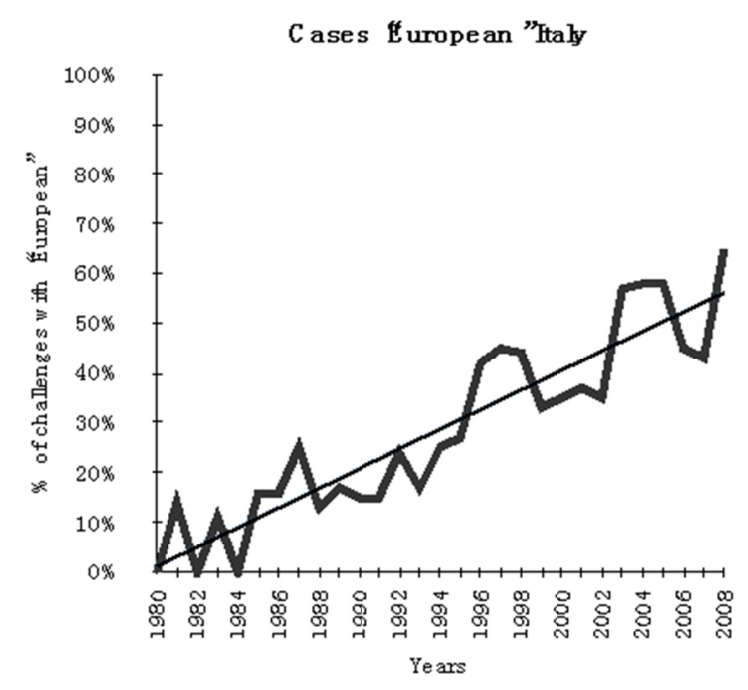

Figure 1. Development of "European influence" in Italy in the period between 1980 and 2008

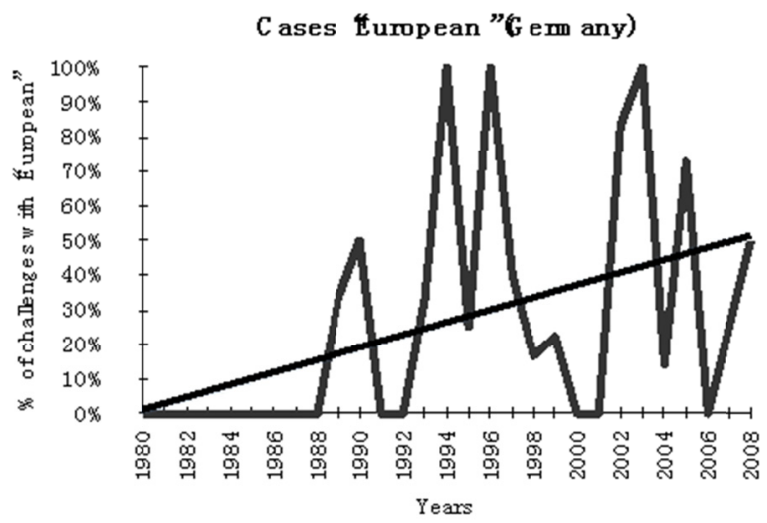

Figure 2. Development of "European Influence" in Germany in the period between 1980 and 2008

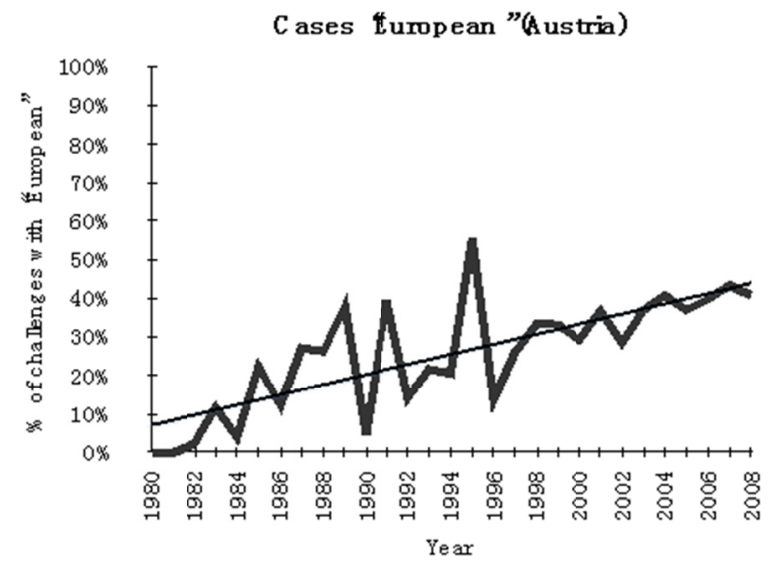

Figure 3. Development of "European influence" in Austria in the period between 1980 and 2008 
Figures 1, 2 and 3 show a steady increase of the usages of European influence in the court decisions of the German, Austrian and Italian constitutional court. In terms of theoretical paradigms and applications, such a shift from "European influence" from a purely formal to a more differentiated usage outside of direct regulatory references can be linked to a more sociological institutionalist understanding of Europeanisation.

\subsection{Austria and European Influence Prior to Membership - Further Empirical Evidence for a Wider Perception of European Influence}

Further evidence for the necessity to broaden and clarify the definition of Europeanisation in regards to courts is apparent when analysing the Austrian development in more detail (Figure 3 above). The increase in references to Europe have been increasing in this jurisdiction prior to membership in 1995, and even prior to application for membership in 1998 (Figure 4). This cements the argument that a view of Europeanisation as a function of the formal pathways and the alterations of opportunity structures within these formal pathways will not be able to account for the whole picture presented by European influence on the courts and national jurisdictions.
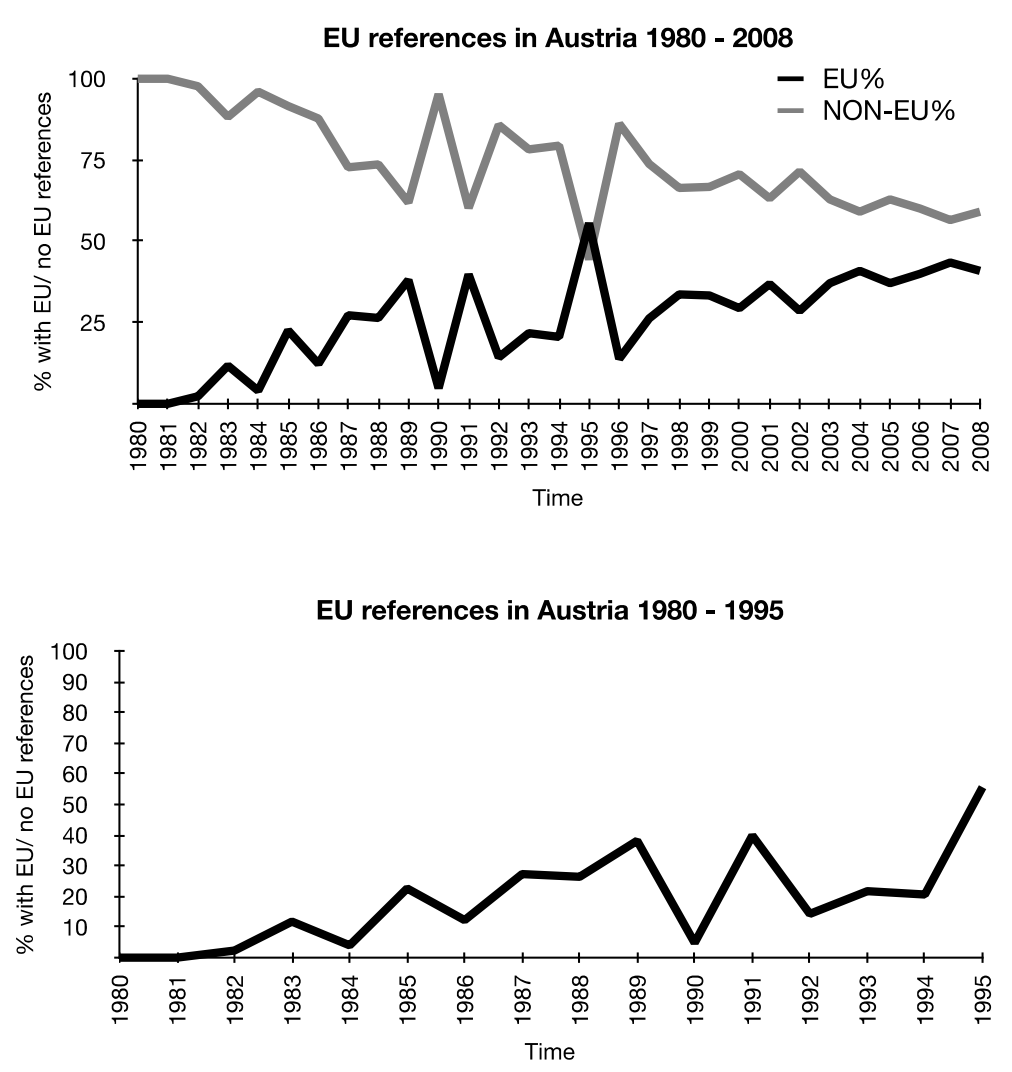

Figure 4. Development of European influence 1980-2008, 1980-1995 in Austria

In Austria, Figure $4 \mathrm{a}$ and $\mathrm{b}$ shows that the increase in informal references to Europe and European norms has increased long before membership. It is true that only in 1995, the number of cases in which there is a reference to "Europe" exceeded the number of non-EU references, and it is furthermore true that in this year the number of "formal references", references to distinct laws and regulations, outweighed informal references such as "European obligations and norms". However, the important aspect of the data is that there is a notable increase in the references to Europe, formal and especially informal, long before there was membership. Moreover, this increase in informal references continued after membership was achieved even though formal pathways were now available. Most importantly, just as in Germany and Italy, this increase excludes Article 267 references. This development, the increase in references to Europe in an informal format even before a nation joins the EU in areas that are untouched by direct review indicates that the concept of Europeanisation, or for that matter the study of European Integration as a whole, needs to allow for informal references. 
Most common assumptions of Europeanisation, as described above, are rooted in rational choice analysis of human or institutional interactions. A change in the opportunity structure at one level, due to the direct link to the supranational level, leads to actors adjusting their expectations and action strategies towards the changed opportunity structure. The data in Figure 1,2,3 and 4 indicates, however, that this is only the first step in the process of Europeanisation. It can be argued that the change in the realisation of the altered opportunity structure will lead to a change in the perception of normative understandings of appropriateness within the minds of the actors. This will then lead to an introduction of less formal perceptions of "European influence". With other words, the above data contravenes two of the three assumptions classical Europeanisation theory had been based on regarding courts: a) limitation of influence to Article 267 references and b) influence exclusively in jurisdictions with a direct link between the national and supranational level, direct review and c) linked to formal European Union membership. We have therefore seen that classical Europeanisation theories are limited in their application to Article 267 references in courts but there is an empirical need for a wider analysis.

\subsection{A More Comprehensive Definition of Europeanisation in the Courts}

The empirical data above have shown the need to widen the theory of Europeanisation in order to account for court decisions outside of strict preliminary rulings (Article 267) and outside areas that have direct and clear links between the national and the supranational levels. Furthermore the discussion on Europeanisation has also shown that the current state of theory has difficulties to allow for such a broadening of the definition. This paper attempts to refine the definition of Europeanisation so that it is possible to test the theory of Europeanisation to the data. Theories exist and arise from definitions, however the two are correlated subsequently. A definition indicates, potentially precludes or favours, certain theories over others, gives predominance to certain theoretical concepts. The definition of Europeanisation commonly employed and discussed above is intimately linked to rational choice approaches.

\subsection{Rational Choice or Sociological Institutionalism?}

In the search for a wider definition of Europeanisation and explanation of the process thereof that accounts for less formal developments rational choice approaches fall short. It might be argued that embedding such a form of Europeanisation into sociological institutionalist theories might be more successful. This paper however argues that this either/or approach fails to do justice to either the theoretical or the empirical framework surrounding European Union research. Rather, Europeanisation shows the national development to move through distinct and consecutive stages moving from pure European Integration, to rational choice Europeanisation to a more sociological Europeanisation to which a sociological institutionalist Europeanisation theory is most applicable. As a result, the definition of Europeanisation needs to be more precise, empirically relevant and theoretically relevant to allow to a firm grounding of any theoretical debate.

Radaelli (2003) argues that the research in Europeanisation suffers from conceptual issues relating to the basic concept and our understanding of the background concept. He suggests the building of a concept dialectically, based on existing hypothesis, allowing for background concepts, rival explanations and empirical observations (Radaelli, 2003:31). The background concepts are comparable if the theory is applied to other areas or the study of courts. The first question that needs to be answered is: How does Europeanisation occur? Is it an incremental development or a discontinuous jump? The definition of Europeanisation discussed above defines it as a "process", which suggests an incremental development. Europeanisation defined as Article 267 references, how it is measured in relation to courts, suggests a discontinuous jump. Drawing on the literature on organisational and personal learning the "developmental process" can be defined generally as a:

"combination of processes...whereby the whole person (knowledge, skills, ATTITUDES, VALUES, emotions, beliefs....), or a group of persons organised within an institutional framework, experience social situations, the perceived content of which is then transformed cognitively, emotively or practically and integrated into the existing knowledge and belief system resulting in a continually changing action, belief and value framework" (Jarvis, 2009: 25).

When applied to Europeanisation in the courts the definition can be specified by describing Europeanisation as a process in which a whole person (knowledge, skills, ATTITUDES, VALUES, emotions, beliefs....), or a group of persons organised within an institutional framework such as a court, experience social and professional situations with European content, the perceived content of which is then transformed cognitively, emotively or practically and integrated into the existing knowledge, rule and belief system resulting in a continually changing action, belief and value framework now containing evidence of "European" influence.

This definition has the additional advantage of being able to account for the concepts of epistemic communities and judicial comity. Epistemic communities is a common concept in international relations theories, and in 
environmental politics in the EU, both in an ad hoc and a more permanent capacity (Antoniades, 2003: 22; Adler, 1992; Galbreath, 2012). The difference to the above definition of Europeanisation lies in the level of intent, of conscious design. Epistemic communities, as they were originally understood, were formed for the purpose and because of a common policy goal within a specified policy area (Haas, 1992:3). Europeanisation, according to the above definition, allows for this development to be more gradual, less intentional and less limited to a specific policy area. It is analysed as a more "natural" development.

In some ways, Europeanisation is a result of judicial comity, as well as creating a precondition for it. Judicial comity is the legal practice common in international law of respecting decisions by other jurisdictions, decisions not in conflict with national law, based on shared basic legal principles (Petersman, 2013:6). Europeanisation, as understood here, is the reason for the recognition and development of shared basic legal principles, as well as creating a feedback loop, which then feeds back into the respect towards the decisions of other jurisdictions. Furthermore, it applies not only to the decisions of the courts but every aspect and member of the judicial and political decision framework.

Therefore the above nominal definition allows for formal and informal aspects without losing the clear link between the "European" and the "Europeanised" with preserving the "process" aspect of the definition. However, the problem of measurement and internal validity has to be addressed in an empirical definition applicable to the research question, in this instance courts and abstract judicial review. The Article 269 definition of Europeanisation, as used in most current research, was very limited in its definitional scope, due to its firm base in rational choice theoretical paradigms. A wider definition, as the one presented above, needs a different theoretical backing.

\section{A 2-Stage Test for Europeanization}

Europeanisation as a process as developed through rational choice institutionalism predicts an adaptation at a national level to European governance structures due to altered opportunity structures. In research, the debate has always been if this change in opportunity structures can be a change in social norms rather than tangible policy change. The above definition allows for just such a change in social norms, however, using sociological europeanisation in combination to rational choice allows also for measurement and breadth of definition. This is especially useful in respect to courts as it allows for a more comprehensive measurement of European influence as it develops and applies to the legal system. What does this mean in concrete terms?

In the original, non-Europeanised state of politics, the constitutional court considers a case purely in a national setting against the national legal framework. In this situation, the plaintiffs and other actors within the system base their decisions on the incentive structure within the national constitutional system, as does the court. In regards to the non-legal actors this means for example the use of the court as a veto-player (Volcansek, 1994; Volcansek, 2000), as a threat within parliamentary debates (Landfried, 1994) or as a protector of minority rights (Vanberg, 2005; Kramer, 2007). In regards to a court, the incentive structure is slightly different but not less important. The court's interest lies in preserving the viability of its decisions, protecting the rule of law and the constitution. These three goals are interlinked as viability depends on the adherence to the rule of law and constitution as this minimises the chances of a higher or subsequent court overruling a decision (Epstein, Knight et al., 2001; Whittington, 2005; Spaeth, 2010). Therefore a constitutional court in the normal constitutional system is less vulnerable to be overruled than lower courts as it holds the highest position within the system. This is the rational choice view of decision-making within a court system. However, this view has been supplemented with other approaches which look at the method in which a court makes decisions. They see decision-making altered by the incentive structure surrounding the courts (Domingo, 2000; Kramer, 2004; Kramer, 2007). The level of public trust in the court affects the range of possible actions as does the level of independence of the court (Ferejohn \& Kramer, 2006; Kramer, 2007). The format and language of a decision impacts the perception of the decision in the wider political surrounding and therefore guides its reception (Posner, 1995). Political and personal attitudes of individual judges matter as well as their value and norm framework (Segal \& Cover, 1989; Segal, Epstein et al., 1995; Segal \& Spaeth, 1996; Segal \& Spaeth, 2004). The level to which these value and norm frameworks coincide with the wider public, will, on the other hand, affect the level of trust that is given to courts and therefore feed back directly again into the viability of the decision of a court.

The German Constitutional Court is a good example for this image of a court within a wider political and normative structure. The German Constitutional Court is a major actor within the political system of the Federal Republic (Kommers, 1997). It is perceived, and perceives itself, as a safeguard against violations of the constitution and as a protector of minorities (Limbach, 2000). Due to Germany's past this is a mission statement strongly approved by the public and as a result decisions based on this principle are rarely challenged (Lijphart, 
1991; Lijphart, 2004). Within the system it is simply not acceptable to perceive a situation in which the fundamental rights of minorities are not protected. Using organisational theory and a logic of appropriateness it can be explained as follows: Organisational analysis holds that the decisions of a bounded rational actor is not based solely on the consequences of an action but also on the expectations of behaviour attached to the membership and roles held within an organisation (March, 1999: 14; Hatch \& Yanow, 2003: 73). The German constitutional court sees itself as the protector of minorities, the protector of the constitution. This is part of the role of being a judge at the constitutional court and a decisions based on the assumption that minorities should not be protected is therefore inconceivable.

So prior to Europeanisation courts and other institutions try to achieve their goals based on the incentive structure surrounding them and the perception they have of their own role in the organisation and society as a whole. Part of this incentive structure is the political and constitutional frameworks surrounding a court, in the instance of a high court the incentive structure includes its own position, on top of the pecking order. Membership of the EU and the development of the powers of the European Court of Justice (ECJ) has changed this position on top of the pecking order considerably (Wincott, 2000; de Burca \& Weiler, 2001). The incentive structure now includes a tier above the high courts. This is all very well encompassed by the theories that see Europeanisation through increased Article 267 references as this is the link to the higher tier, the European tier. But the problem is that development do not simply stop. The European Court of Justice has engaged in a strategic campaign to change the way itself is seen in the eyes of national court and the way in which national courts seem themselves within the wider European system (Mattli \& Slaughter, 1998; Alter, 2001) in order to achieve its goal: more Article 269 references. However changes in perceptions of one's own role or the role of an institution cannot be simply confined to a small amount of cases, Article 267, but will spread further.

As soon as the role perception has shifted in one are this will take affect in other areas of legal reasoning as well. In interviews with members of the German, Austrian and Italian constitutional courts in 2008 at least two third of the judges saw themselves as adjudicating within a European legal system and the majority expressed the belief that their role is not only to protect the national constitutional system but the European one as well (Table 1). They saw the two as being closely linked and containing the European norms they were sworn to stand for. So a clear shift has occurred in the way a judge perceives her own role to be understood within the wider legal system. An Europeanisation of a more normative format has occurred which then can explain the increased use of informal references to the "European" within decision texts (Figure 1,2,3 above).

Table 1. Role-Perception of judges

\begin{tabular}{ccccc}
\hline & Germany & Austria & Italy & Total \\
\hline Non- European & 4 & 6 & 1 & 11 \\
European & 8 & 10 & 9 & 27 \\
\hline
\end{tabular}

Description: Results to the interview question: "Would you classify your role to be within a European or purely national legal system?"

The Europeanisation process here can therefore be argued to be a 2-stage process. The first state is a reaction to a changed incentive structure as can easily be explained by a rational choice institutionalist theoretical approach (Buller \& Gamble, 2002). The second stage develops out of the first stage through a process of learning, of adaptation of the mental and intellectual framework within an institution and actor, under which decisions are taken. Therefore the process of Europeanisation progresses as follows:

1. Stage: Europeanisation by rational choice

At this place little has to be said about this stage of Europeanisation as it is well-documented (Conant, 2001; Nyikos, 2008; Ladrech, 2010). "The goodness of fit between domestic institutions and European requirements determines the extent to which Europeanisation generates pressures for adaptation in national legal structures" (Conant, 2001: 100). This is due to the fact that national courts are dependent on plaintiffs involving them into the decision-making process as they have no automatic presence (Ladrech, 2010: 115). "Legal change (at the European level) does not directly affect a national court until a related case is brought before it. Even then, it can ignore European law. It is only when a national court chooses to interpret the effects of EC law upon national law, or to engage in judicial dialogue with the European Court of Justice, that it is directly affected by Europeanization. And it is thus that the national court steps one timid foot upon the slippery slope from national to European court." 
(Nyikos, 2008: 183). The reason why the court chooses to step onto this slippery slope is because whilst the legal framework in which it acts has changed its goals have not. It whishes to pass laws that will stand the test of time and protect the rule of law. Therefore it has to engage with the European level or risk having its decision overturned (viability of laws) or deny its citizens the access to justice and advantages provided through the European level (rule of law). This was emphasised to the courts by direct interaction and lobbying of the ECJ (Alter, 2001) and by the professional need to widen basic knowledge towards other jurisdiction and the European level.

Table 2. Europeanization process before and after

\begin{tabular}{|c|c|c|}
\hline constitutional courts $(C C)$ & pre-Europeanisation & post-Europeanisation \\
\hline Actors & $\mathrm{CC}$, lower courts, public & ECJ, CC, lower courts, public \\
\hline incentive structure & no higher courts has power & empowered ECJ \\
\hline environment & no Article 267 & $\begin{array}{l}\text { Article } 267 \\
\text { - } \quad \text { lower courts can refer to ECJ or CC }\end{array}$ \\
\hline pressures & lower courts refer to $\mathrm{CC}$ & $\begin{array}{l}\text { - } \quad \text { increased academic knowledge } \\
\text { - } \quad \text { increased practical knowledge }\end{array}$ \\
\hline goals & \multicolumn{2}{|c|}{ endurance of decisions } \\
\hline technology & $\begin{array}{l}\text { no jurisdiction aside from nation one } \\
\text { matters }\end{array}$ & other jurisdictions (EU) need to be considered \\
\hline
\end{tabular}

Description: Tabular representation of the Europeanization process from the beginning point (pre-Europeanization) to the endpoint (post-Europeanization). The table therefore shows how there is a distinct and measurable change.

Therefore the national court accepts that the legal framework and the incentive structure surrounding it have changed and learns how to adapt to this new system that includes Article 267 references. However, due to the fact that the court cannot act in isolation but needs to be approached by external actors to take action, it is predictable that Europeanisation moves at different speeds in different areas of law dependent on the degree of misfit and the degree of available actors in these areas (Ladrech, 2010: 98).

2.Stage: Sociological Institutional Europeanisation

However, this Europeanisation does not simply stop with the national court accepting that there is another level, a European level, that can be addressed and, based on the theorised understanding of learning above, learns how to do this. The process in which it learns to do so changes something fundamental on the self-perception of the court and the individuals. It becomes a European court, as Nyikos calls it (Nyikos, 2008: 184). To accept that there is a higher level, at least in European questions initially, means the shift in the perception of where the court is situated within the system and what it stands for. The need to allow for considerations of concerns that might have their origin in non-national or other-national issues and legislative systems or legal considerations necessitates a different approach to the law. The law is not anymore purely national and insular but needs to be considered in a wider range of perceptions and knowledge requirements. Today, at least half of all the judges serving at the constitutional courts of Germany, Austria and Italy have either studied, taught at a foreign university or have served at a European court. Most have some background in EU law as well (Figure 5).

Therefore, already based on their education and socialisation they have a more European outlook than would have been the case decades ago. Moreover, by changing the incentive structure to that of a European court the cultural-cognitive structure surrounding the court has changed. With cultural-cognitive structure I mean here "the beliefs and understandings that participants share about the nature of their situation and interests" (Scott, 2003: 19). They are not anymore simply the protectors of national constitutions and norms but of European ones. A paradigm shift has occurred that will not be limited to simply the cases with Article 267 relation.

In this second stage the above definition of Europeanisation as a process in which a whole person (knowledge, skills, ATTITUDES, VALUES, emotions, beliefs....), or a group of persons organised within an institutional framework such as a court, experience social situations with European content, the perceived content of which is then transformed cognitively, emotively or practically and integrated into the existing knowledge and belief 
system resulting in a continually changing action, belief and value framework now containing evidence of "European" influence is then realised.

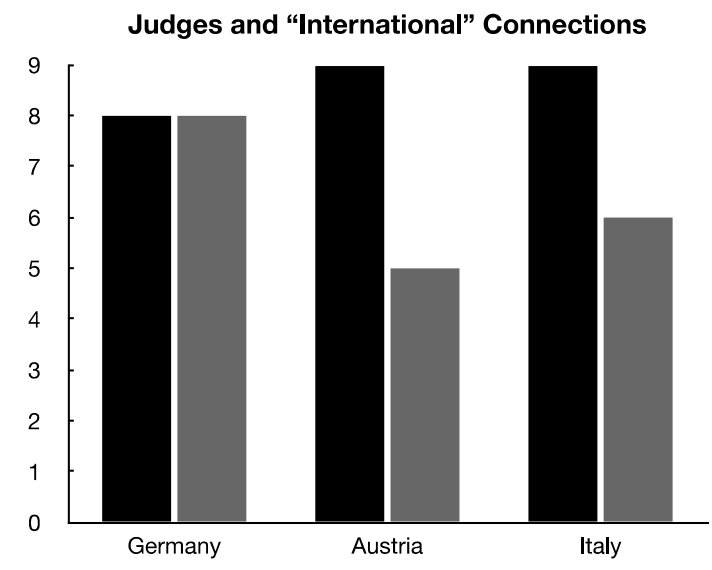

Figure 5. Number of judges with an international connection - having studied or taught at a foreign university or served at a European court

Table 3. Tabular representation of the 2-stage Europeanization process

\begin{tabular}{|c|c|c|}
\hline constitutional courts (CC) & 1. Stage & 2. Stage \\
\hline Actors & ECJ, CC, lower courts, public & $\begin{array}{l}\text { ECJ, CC, lower courts, public, } \\
\text { international universities and courts }\end{array}$ \\
\hline incentive structure & empowered ECJ & $\begin{array}{c}\text { empowered ECJ, international career } \\
\text { structure }\end{array}$ \\
\hline environment & Article 267 & $\begin{array}{l}\text { Article } 267, \text { judges with international } \\
\text { socialization }\end{array}$ \\
\hline pressures & $\begin{array}{l}\text { lower courts can refer to ECJ or CC } \\
\text { increased academic knowledge } \\
\text { increased practical knowledge }\end{array}$ & $\begin{array}{l}\text { international academic structure } \\
\text { international career structure } \\
\text { international knowledge requirements } \\
\text { European norm perception }\end{array}$ \\
\hline goals & \multicolumn{2}{|c|}{ endurance of decisions } \\
\hline technology & $\begin{array}{l}\text { no jurisdiction aside from nation one } \\
\text { matters }\end{array}$ & $\begin{array}{l}\text { other jurisdictions (EU) need to be } \\
\text { considered }\end{array}$ \\
\hline
\end{tabular}

Description: Tabular representation of the two distinct stages of Europeanization, with the first stage encompassing the more formal and the second stage the more informal aspects.

\section{Alternative Explanations - Legalism and Formal Legal Theory}

Ladrech suggests that to test for Europeanisation one should employ counter factual reasoning and ask if the same development would have occurred without the EU (Ladrech, 2010: 34). So would the 2-stage Europeanisation have occurred without the EU? Clearly stage one would not have occurred as there would not be a change in the incentive structure through an introduction of Article 267. But would Stage 2 have occurred? It could be argued that life in general has allowed us to be more mobile and that therefore the educational path of people would have changed to a more international one even without the EU. However, this is not enough to cause a paradigm shift in the perceptions of participants as to what the role of the courts and the judges is. There would be no need for the international connection to impact on the national system as there would be no legal room to allow it impact. Without a change in the perception in the position of the court as a member of a European system there is no "European" influence as evidence by Figure 1,2,3. 
But are there alternative explanations for this development? The increase in Article 267 references can be accounted for with formal legalist theory. In this view the law is a closed system and no other considerations aside from the black letter of the law or precedent impact the judge in his or her decision. In this view Article 267 can be seen as part of the closed system. As soon as the treaty had been passed and the national legislatives have passed the provision that it applies to the national legal system a court is obliged to apply it. It becomes part of the national system and therefore the closed system. However, even in this view the majority of theorists allow for the fact a certain amount of interpretation is possible for the judge (Dworkin, 1998; Whittington, 2000; Dworkin, 2006; Posner, 2008; Ladrech, 2010: 115). However, Stage 2 cannot be encompassed by this theory as informal uses of "European" should not have been important to the decision at all. No change in the number of informal uses of "European", definitely not as norms, values or obligations, should be noticeable in Figure 1,2,3,4 or 5. Therefore, legalism in unable to account for this increase.

A more interesting proposition is the relationship between Europeanization and the theory of judicial dialogue, prevalent in legal sciences. Judicial dialogue suggests a view of the national and international legal and political systems, which exchange actions in response to those in other areas (Jacobs, 2003: 549). In some ways, it is without a doubt arguable that Europeanization, as described here, could not be argued to be a form of judicial dialogue, at least if the concept if judicial dialogue were to be adapted and widened. As yet, the study of judicial dialogue is based on formal interactions and would be unable to account for a horizontal Europeanization process between unrelated fields (Ming Sung, 2013).

\section{Europeanization and the Arguments against Integration}

In recent years arguments have pointed to a retrenchment in regards to European Integration, especially in the judicial area. Especially the use of the ultra vires and counter limits doctrines are examples often cited for this argument. Any attempt to create a working definition of Europeanization has to be able to account for this development. Ultra vires denotes the legal concept, which separates the legal decision arena into distinct areas of influence, into little boxes in which a court has jurisdiction, in comparison to areas outside these boxes, which are the jurisdiction of other courts. It is traditionally a concept based on Anglo-Saxon jurisdictions and had been applied widely in corporate law, but has in the last decade and a half also found its way into EU law. The most famous examples of this can be found in the Czech constitutional court's decision regarding Landtová (C-399/09). The counter-limits doctrine, as used by the Italian constitutional court in the Federfarma decision (4207/2005), is based on the same principle of there being clear lines of jurisdiction between the EU level and the national levels. The emergence of these formal retrenchment capability are issues the theory of Europeanization has to address, though this paper is not the place as it argued for informal European influence developing outside the formal mechanisms. Nevertheless, a few comments are in order. The simple fact that there are retrenchments, debates and reactions comparable across nations denotes not only a form of influence, but shared values.

\section{Conclusion}

This paper therefore develops a 2-Stage test which allows for the capture of formal as well as informal aspects of the concept of Europeanisation. The first-stage is a rational choice based adaptation to new incentive structures within a legal system. Traditional theories can easily account for this and are able to allow for the varying levels of Europeanisation in different areas of law through dissimilar levels of legal mobilisation within the areas of law. The problem has always been to account for less formal trends of Europeanisation. This paper argues that they are an automatic consequence of the first stage of Europeanisation as well as due to Europeanisation of the social and career structures. The first stage of Europeanisation affects the way participants perceive their own position and goals within an organisation, such as a constitutional court. It becomes more than a national court, it becomes a European court (distinct from a European Union Court) and this change in self-perception of the participants results in horizontal Europeanisation of a normative nature.

\section{References}

Adler, E., \& Haas, P. M. (1992). Conclusion: Epistemic Communities, World Order, and the Creation of a Reflective Research Program. International Organization, 46(1), 367-390. http://dx.doi.org/10.1017/S0020818300001533

Alter, K. J. (2001). Establishing the Supremacy of European Law. Oxford: Oxford University Press.

Antoniades, A. (2003). Epistemic Communities, Epistemes and the Construction of (World) Politics. Global Society, 17(1), 21-38. http://dx.doi.org/10.1080/0953732032000053980

Aronson, E. (2004). The Social Animal. New York: Worth Publishing.

Barnett, H. (2004). Constitutional and Administrative Law. London, Cavendish Publishing. 
Boerzel, T. A. (2005). Europeanization. The member states of the European Union. S. Bulmer and C. Lequesne. Oxford: Oxford University Press.

Boerzel, T. A., \& Cichowski, R. (2003). The State of the European Union. Oxford: Oxford University Press. PMid:12611529

Boerzel, T. A., \& Risse, T. (2000). When Europea hits home: Europeanization and Domestic Change. European Integration online Papers, 4(15).

Boerzel, T. A., \& Risse, T. (2007). Europeanization: The domestic impact of EU politics. In E. Knud, M. Pollak, \& B. Rosamond (Eds.), Handbook of European Union Politics. London: Sage.

Buller, J., \& Gamble, A. (2002). Conceptualising Europeanisation. Public Policy and Administration, 17(4), 4-24.

Camerer, C. F., \& Fehr, E. (2002). Measurung Social Norms. Institutte for Empirical Research Working Paper Series University of Zurich 97.

Comella, V. F. (2009). Constitutional Courts and Democratic Values. New Haven: Yale University Press.

Conant, L. (2001). Europeanization and the Courts. transforming Europe. M. G. Cowles, J. Capraso and T. Risse. Ithaca: Cornell University Press.

Conant, L. (2002). Justice Contained. Ithaca: Cornell University Press.

Craig, P., \& Burca, G. D. (2003). EU Law. Oxford: Oxford University Press.

de Burca, G., \& Weiler, J. (2001). The European Court of Justice. Oxford: Oxford University Press.

Domingo, P. (2000). Judicial Independence: The Politics of the Supreme Court in Mexico. Journal of Latin American Studies, 32, 705-735. http://dx.doi.org/10.1017/S0022216X00005885

Dworkin, R. (1998). Law's Empire. Oxford, Hart Publishing.

Dworkin, R. (2006). Justice in Robes. Cambridge, Belknap.

Elster, J. (1998). Social Norms and Economic Theory. Journal of Economic Perspectives, 3(4).

Epstein, L., \& Knight, J. (2001). The role of constitutional courts in the maintenance of democratic systems of government. Law and Society Review, 35(1), 117-164. http://dx.doi.org/10.2307/3185388

Ferejohn, J., \& Kramer, L. D. (2006). Judicial independence in a democracy: institutionalizing judicial restraint. Cambridge New York: Cambridge University Press.

Galbreath, D. J., \& McEvoy, J. (2012). How Epistemic Communities Drive International Regimes: The Case of Minority Rights in Europe. Journal of European Integration, 35(2), 169-186. http://dx.doi.org/10.1080/07036337.2012.692117

Garrett, G., \& Kelemen, D. (1998). The European Court of Justice: Master or Servant. International Organization, 52, 149-176. http://dx.doi.org/10.1162/002081898550581

Haas, P. M. (1992). Introduction: epistemic communities and international policy coordination. International Organization, 46(1), 1-35. http://dx.doi.org/10.1017/S0020818300001442

Harding, A., \& Leyland, P. (Eds.). (2009). Constitutional Courts - A comparative Study. JCL Studies in Comparative Law. London: Wildy, Simmons and Hill.

Hatch, M. J., \& Yanow, D. (2003). Organisation theory as an interpretative science. In H. Tsoukas, \& C. Knudsen (Eds.), The Oxford Handbook of Organization Theory. Oxford, Oxford University Press.

Haverland, M. (2003). Methodology. The Politics of Europeanisation. K. Featherstone and C. Radaelli. Oxford: Oxford University Press. PMid:14552819

Hix, S. (2000). Introduction: European Integration and national political systems. West European Politics, 23(4). http://dx.doi.org/10.1080/01402380008425398

Howell, K. (2004). Developing Conceptualisations of Europeanisation. Queen's Papers on Europeanisation, 3.

Jackson, D. W., \& Tate, C. N. (1992). Comparative Judicial Review and Public Policy. Westport: Greenwood Press.

Jacobs, F. G. (2003). Judicial Dialogue and the Cross-Fertilization of Legal Systems: The European Court of Justice. Texas International Law Journal, 38(3), 547-556. 
Jarvis, P. (2009). Learning to be a person in society. In K. Illeris (Ed.), Contemporary Theories of Learning. Abingdon: Routledge.

Kahan, D. M. (1997). Social Influence, social meaning and deterrence. Virginia Law Review. http://dx.doi.org/10.2307/1073780

King, G., \& Keohane, R. (1994). Designing Social Inquiry. Princeton: Princeton University Press.

Kommers, D. P. (1997). The Constitutional Jurisprudence of the Federal Republic of Germany. Durham: Duke.

Kramer, L. D. (2004). The People Themselves. Oxford: Oxford Univeristy Press.

Kramer, L. D. (2007). The people themselves: popular constitutionalism and judicial review. Journal of interdisciplinary history, XXXVII(3), 462-463.

Kuo, M. S. (2013). Discovering Sovereignty in Dialogue. Canadian Journal of Law and Jurisprudence, 26.

Labovitz, S., \& Hagedorn, R. (1973). Measuring Social Norms. The Pacific Sociological review, 16(3), 283-303.

Ladrech, R. (2010). Europeanization and National Politics. New York: Palgrave.

Landfried, C. (1994). The Judicialization of Politics in Germany. International Political Science Review, 15(2), 113-124. http://dx.doi.org/10.1177/019251219401500203

Lessig, L. (1996). Social Meaning and Social Norms. University of Pennsylvania Law Review, 144(5), 2181-2189. http://dx.doi.org/10.2307/3312651

Lijphart, A. (1991). Constitutional Choices for New Democracies. Journal of Democracy, 2(1), 72-86. http://dx.doi.org/10.1353/jod.1991.0011

Lijphart, A. (2004). Constitutional Design for Divided Societies. Journal of Democracy, 15(2), 96-109. http://dx.doi.org/10.1353/jod.2004.0029

Limbach, J. (2000). Das Bundesverfassungsgericht. Heidelberg: C.F.Mueller.

Mancini, G. F. (1991). The Making of a Constitution for Europe. In R. Keohane, \& H. Stanley (Eds.), The New European Community. Boulder: Westview Press.

March, J. G. (1999). The pursuit of organisational analysis. Oxford: Blackwells Publishers.

Mattli, W., \& Slaughter, A. M. (1998). Revisiting the European Court of Justice. International Organization, 52(1), 177-209. http://dx.doi.org/10.1162/002081898550590

Nyikos, S. A. (2008). Courts. Europeanization: New Research Agendas. P. Graziano and M. P. Vink. Basingstoke, Palgrave, Macmillan.

Olson, J. (2002). The Many Faces of Europeanisation. Journal of Common Market Studies, 40(5), 921-952. http://dx.doi.org/10.1111/1468-5965.00403

Peters, G. B. (2005). Institutional Theory in Political Science: The New Institutionalism. Continuum International Publishing Group.

Petersmann, E. U. (2013). The Judicial Task of Administering Justice in Trade and Investment Law and Adjudication. Journal of International Dispute Settlement, 4(1), 5-28. http://dx.doi.org/10.1093/jnlids/ids011

Posner, R. (1995). Judges' Writing Styles (And Do They Matter?). The University of Chicago Law Review, 62(4), 1421-1449. http://dx.doi.org/10.2307/1600108

Posner, R. (2008). How Judges Think. London: Harvard University Press.

Radaelli, C. (2000). Whither Europeanization? Concept stretching and substantive change. European Integration online Papers, 4(8).

Radaelli, C. (2003). The Europeanization of public policy. In K. Featherstone, \& C. Radaelli (Eds.), The Politics of Europeanization (pp. 27-56). Oxford: Oxford University Press.

Radaelli, C. (2004). Europeanisation: Solution or problem? European Integration online Papers, 8(16).

Reno, R. R., \& Cialdini, R. B., et al. (1993). The transitional influence of social norms. Journal of Personality and Social Psychology, 64(1), 104-112. http://dx.doi.org/10.1037/0022-3514.64.1.104

Risse, T., \& Cowles, M. G., et al. (Eds.). (2001). Transforming Europe: Europeanisation and Domestic Change. London: Cornell University Press.

Rogowski, R., \& Gawron, T. (2002). Constitutional Courts in Comparison. New York: Berghahn. 
Schultz, P. W., Nolan, J. (2007). The Constructive, Destructive, and Reconstructive Power of Social Norms. Psychological Science, 18(5), 429-434. http://dx.doi.org/10.1111/j.1467-9280.2007.01917.x PMid:17576283

Scott, R. W. (2003). Organization: rational, natural and open systems. Englewood-Cliffs: Prentice Hall.

Segal, J. A., \& Cover, A. D. (1989). Ideological values and the votes of U.S. Supreme Court justices. American Political Science Review, 83(2), 557-565. http://dx.doi.org/10.2307/1962405

Segal, J. A., \& Epstein, L. (1995). Ideological values and the votes of U.S. Supreme Court justices revisited. Journal of politics, 57(3), 812-823. http://dx.doi.org/10.2307/2960194

Segal, J. A., \& Spaeth, H. J. (1996). Norms, dragons, and stare decisis: a response. American Journal of Political Science, 40(4), 1064-1082. http://dx.doi.org/10.2307/2111743

Segal, J. A., \& Spaeth, H. J. (2004). The Supreme Court and the attitudinal model revisited. Journal of politics, 66(4), 1304-1306.

Slaughter, A. M. (2012). A new world order. Princeton: Princeton University Press.

Slaughter, A. M., \& Stone Sweet, A. (1998). The European Courts and National Courts. Oxford: Hart publishing.

Slepcevic, R. (2009). The judicial enforcement of EU law through national courts: possibilities and limits. Journal of European Public Policy, 16(3), 378-394. http://dx.doi.org/10.1080/13501760802662847

Spaeth, H. (2010). Reflections about Judicial Politics. In K. Whittington, D. Kelemen, \& G. Caldeira (Eds.), The Oxford Handbook of Law and Politics. Oxford: Oxford University Press.

Stone Sweet, A., \& Sandholtz, W. (2001). The Institutionalisation of Europe. Oxford: Oxford University Press. http://dx.doi.org/10.1093/019924796X.001.0001

Stone Sweet, A., \& Stranz, K. (2011). Rights adjudication and constitutional pluralism in Germany and Europe. Journal of European Public Policy, 19(1), 92-108. http://dx.doi.org/10.1080/13501763.2012.632148

Sunstein, C. R. (1996). Social Norms and Social Roles. Columbia Law Review. http://dx.doi.org/10.2307/1123430

Vanberg, G. (2005). The Politics of Constitutional Review in Germany. Cambridge: Cambridge University Press.

Volcansek, M. (2000). Constitutional Politics in Italy. London: Macmillan Press.

Volcansek, M. L. (1994). Political-Power and Judicial-Review in Italy. Comparative Political Studies, 26(4), 492-509. http://dx.doi.org/10.1177/0010414094026004005

Whittington, K. E. (2000). Dworkin's 'originalism': the role of intentions in constitutional interpretation. Review of Politics, 62(2), 197-229. http://dx.doi.org/10.1017/S0034670500029442

Whittington, K. E. (2005). Interpose your friendly hand. American Political Science Review, 99(4), 583-596.

Wincott, D. (2000). A Community of Law? European Law and Judicial Politics: The Court of Justice and Beyond. Government and Opposition, 35(1), 3-26. http://dx.doi.org/10.1111/1477-7053.00009

\section{Notes}

Note 1. This is a simplified view as other courts, civil courts, have developed ways of direct judicial review of legislation REF.

Note 2. The question of legality does not strictly speaking enter the question as, outside of equal pay, gender discrimination is regulated through case law (no anti-discrimination clause regarding women in the US Constitution) and therefore the Supreme Court itself.

Note 3. at least in regards to the increase within the borders of the EU

\section{Copyrights}

Copyright for this article is retained by the author(s), with first publication rights granted to the journal.

This is an open-access article distributed under the terms and conditions of the Creative Commons Attribution license (http://creativecommons.org/licenses/by/3.0/). 